\title{
Effect of melatonin on antioxidant capacity, Inflammation and apoptotic cell death in lung tissue of diabetic rats ${ }^{1}$
}

Didem Onk', Oruç Alper Onk", Hüseyin Serkan Erol"', Mustafa Özkaraca'v', Selim Çomaklı' Ayazoğluv, Ufuk Kuyrukluyıldız ${ }^{\mathrm{v}}$, Süheyla ÜnvervıI

'Assistant Professor, Department of Anesthesiology and Reanimation, Faculty of Medicine, Erzincan University, Turkey. Design of the study, acquisition of data, manuscript preparation.

"Associate Professor, Department of Cardiovascular Surgery, Faculty of Medicine, Erzincan University, Turkey. Acquisition of data.

I'Assistant Professor, Department of Biochemistry, Faculty of Veterinary, Atatürk University, Erzurum, Turkey. Acquisition and interpretation of data.

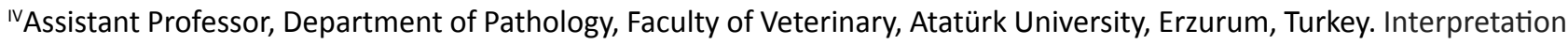
of data.

${ }^{\vee}$ Associate Professor, Department of Anesthesiology and Reanimation, Göztepe Training and Research Hospital, Istanbul, Turkey. Design of the study.

V'Associate Professor, Department of Anesthesiology and Reanimation, Faculty of Medicine, Erzincan University, Erzincan, Turkey. Acquisition of data.

VIIFull Professor, Department of Anesthesiology and Reanimation, Faculty of Medicine, Erzincan University, Turkey. Manuscript writing.

\begin{abstract}
Purpose: To investigate the effects of melatonin on antioxidant capacity, inflammation and apoptotic cell death (through expression of cleaved-caspase 3 ) in lung tissue samples of diabetic rats.

Methods: Thirty male Sprague-Dawley rats were randomly divided into three groups. Group 1 (control group) was made up of healthy rats. Group 2 (diabetes group) received streptozotocin at a dose of $50 \mathrm{mg} / \mathrm{kg} /$ day for 5 days.Group 3 (diabetes plus melatonin group) received streptozotocin at a dose of $50 \mathrm{mg} / \mathrm{kg} /$ day for 5 days and then they received melatonin at a dose of $20 \mathrm{mg} / \mathrm{kg} /$ day between $28^{\text {th }}$ and $35^{\text {th }}$ days of the study.

Results: Tissue MDA and MPO levels were found to be significantly higher in diabetes group compared to control group $(p<0.05)$ whilst administration of melatonin was found to significantly lower this increase down to normal levels $(p<0.05)$. Bronchus associated lymphoid tissue (BALT) was more severe in diabetics whereas administration of melatonin alleviated this hyperplasia. Cleaved caspase 3 activity was severe in hyperplastic BALT in diabetic rats however in lowered down to moderate level when melatonin was administered. Conclusion: The melatonin caused an increase in antioxidant capacity and decreased the expression of cleaved-caspase 3.
\end{abstract}

Key words: Melatonin. Lung. Rats. 


\section{Introduction}

Diabetes has several devastating effects on major organ systems through chronic inflammatory processes and poor glycemic control. Patients with diabetes may develop pulmonary dysfunction which may be associated with significant reduction in exercise capacity and decreased activityrelated quality of life ${ }^{1}$. Previous studies demonstrated that patients with diabetes had significant reductions in FEV1, FVC and CODC levels ${ }^{2,3}$. Although there has been some data suggesting that patients with diabetes tend to have decreased microvascular reserve of the lungs and increased risk of chronic hypoxia, the underlying mechanism has not yet been elucidated. Accumulation of collagen in lung tissue may explain the stiffness that is occurring within the lung parenchyma and around the chest wall, as well ${ }^{4,5}$. It has also been established that elastic recoil capacity and muscle strength decreases in patients with diabetes ${ }^{6}$. Moreover, all these changes may worsen the prognosis of the pulmonary infections which are common in patients with diabetes ${ }^{7}$.

Melatonin is a circulating neurohormone that is produced by pineal gland and it has an important role in regulation of circadian rhythm $^{8,9}$. Recent studies demonstrated that melatonin has several functions including immunomodulatory function and anti-aging mediator effects. It has also been suggested that melatonin prevents against cancer of several types and it maintains endothelial integrity and improves leukocyte, erythrocyte and platelet functions ${ }^{10}$.

Studies in diabetic animal models demonstrated that diurnal changes in blood glucose are due to changes in melatonin levels and increased levels of insulin ${ }^{11}$. In another experimental study supporting this, serum melatonin levels decreased and insulin levels increased in Type 2 diabetic Goto Kakizaki rats $^{12}$. It was demonstrated in Genome-wide association studies that specific singlenucleotide polymorphism of the melatonin receptor 2 (MTNR1B) locus was associated with hyperglycemia and type 2 diabetes ${ }^{13-18}$. However, there has been no study focusing on the effect of melatonin on diabetic lung.

The present study sought to investigate the effect of melatonin on antioxidant capacity, inflammation and expression of cleaved caspase 3 which is a known marker of apoptotic cell death in a diabetic rat model.

\section{Methods}

The study protocol was approved by the Ethical Committee of Atatürk University.

Thirty male Sprague-Dawley rats, weighing from 250 to $300 \mathrm{~g}$ (8-10 weeks old) were used in this study. The rats were housed daily, kept under 12-h light-dark cycle and they were permitted to reach water pellet. The testing room was consistently maintained at $22^{\circ}-24^{\circ} \mathrm{C}$. The rats were fed with special diet and they were randomly divided into three groups. Group 1 (control group) was made up of healthy rats. Group 2 (diabetes group) received streptozotocin at a dose of $50 \mathrm{mg} / \mathrm{kg} /$ day for 5 days. Group 3 (diabetes plus melatonin group) received streptozotocin at a dose of $50 \mathrm{mg} / \mathrm{kg} /$ day for 5 days and then they received melatonin at a dose of $20 \mathrm{mg} / \mathrm{kg} /$ day between $28^{\text {th }}$ and $35^{\text {th }}$ days of the study. Beginning from the $3^{\text {rd }}$ day of streptozotocin administration, glucose levels of the rats were begun to be measured daily. At $35^{\text {th }}$ day of the study, rats were given $1.5 \mathrm{mg} /$ $\mathrm{kg}$ of intravenous omnipaque for renal tissue examination and then they were sacrificed with high dose anesthetics. Levels of tissue lipid peroxidase (LPO; MDA (malondialdehyde)), SOD (superoxidedismutase), GSH (glutathioneperoxidase), CAT (catalase) and MPO (myeloperoxidase )were examined at lung tissue samples of each group. Tissue samples were taken from the lung parenchyma and referred to the histopathologic examination for 
detection of inflammation and cleaved caspase 3 .

\section{Histopathological examination}

Lung tissue samples were fixed in $10 \%$ neutral buffered formalin. Paraffin embedded blocks were routinely processed and $5 \mu \mathrm{m}$ thick sections were stained with haematoxylineosin. The samples were examined under a microscope and randomly 10 microscopic fields were examined in $\times 40$ magnification. The histopathological findings in sections were graded as 0 (none), 1 (mild), 2 (moderate), 3 (severe).

\section{Immunohistochemical examination}

After deparaffinization, the slides were immersed in antigen retrieval solution (pH6.0) and heated in microwave for 15 minutes to unmask the antigens. The sections were then dipped in 3\% $\mathrm{H} 2 \mathrm{O} 2$ for 10 minutes to block endogenous peroxidase activity. Sections were incubated at room temperature with polyclonal rabbit active/cleaved caspase 3 antibody for apoptosis (catno. NB600-1235, dilution 1/400; Novus Biological, USA). Expose Mouse and rabbit specific HRP/DAB detection IHC kit were used as follows: sections were incubated with goat anti-mouse antibody, then with streptavidin peroxidase, and finally with $3,3^{\prime}$ diaminobenzidine + chromogen. Slides were counterstained with hematoxylin. Then 10 randomly selected tubules were examined under 20x magnification. Immunoreactivity in the sections were graded as 0 (none), 1 (mild), 2 (moderate), 3 (severe).

\section{Preparation the tissue homogenates}

Lung tissue samples were grinded with liquid nitrogen in a porcelain mortar. For each group, $25 \mathrm{mg}$ of the pulverized samples were collected and $2.5 \mathrm{ml}$ of a buffer solution was added (a different buffer was used for each parameter) and diluted 1 to 100 . The preparation was then put into the homogenizer and homogenized on ice for 10 minutes. The homogenates were filtered through a filterpaper and they were coolly centrifuged at 4 으 in a refrigerated centrifuge using different rotational speeds specific - as reported in the literature - to each enzyme.

\section{Determination of the lipid peroxidation (LPO)}

The level of LPO in lung tissues was determined by estimating malondialdehyde (MDA) using the thiobarbituricacid test. The lung tissues were dissected, weighed, and homogenized in $10 \mathrm{ml}$ of $100 \mathrm{~g} / \mathrm{LKCl}$. The homogenate $(0.5 \mathrm{ml})$ was added to a solution containing $0.2 \mathrm{ml}$ of $80 \mathrm{~g} / \mathrm{L}$ sodium laurylsulphate, $1.5 \mathrm{ml}$ of $200 \mathrm{~g} / \mathrm{L}$ acetic acid, $1.5 \mathrm{ml}$ of $8 \mathrm{~g} / \mathrm{L} \mathrm{2-thiobarbiturate,} \mathrm{and}$ $0.3 \mathrm{ml}$ of distilled water. The mixture was incubated at $98^{\circ} \mathrm{C}$ for $1 \mathrm{~h}$. Upon cooling, $5 \mathrm{ml}$ of $n$-butanol:pyridine $(15: 1)$ was added. The mixture was vortexed for $1 \mathrm{~min}$ and centrifuged at $4000 \mathrm{~g}$ for $30 \mathrm{~min}$. Subsequently, the absorbance of the supernatant was measured at $532 \mathrm{~nm}$. The standard curve was obtained by using 1, 1, 3, 3-tetramethoxypropane. The recovery rate was over $99 \%$. The results were expressed as nmol MDA/g of tissue.

\section{Superoxide dismutase (SOD) activity}

SOD activity was measured according to Sun et al. (1988). SOD estimation was based on the generation of superoxide radicals produced by xanthine and xanthine oxidase, which react with nitroblue tetrazolium (NBT) to form formazan. SOD activity was then measured at $560 \mathrm{~nm}$ by the degree of inhibition of this reaction and was expressed as $\mathrm{mmol} / \mathrm{min} / \mathrm{mg}$ of tissue.

\section{Catalase (CAT) activity}

Decomposition of $\mathrm{H}_{2} \mathrm{O}_{2}$ in the presence of CAT was measured at $240 \mathrm{~nm}$ according to 
Aebi (1984). The CAT activity was defined as the amount of enzyme required to decompose 1 mmolof $\mathrm{H}_{2} \mathrm{O}_{2}$ per minute, at $25^{\circ} \mathrm{C}$ at $\mathrm{pH} 7$. Results were expressed as $\mathrm{mmol} / \mathrm{min} / \mathrm{mg}$ of tissue.

\section{Total glutathione (GSH)}

The lung tissues were homogenized in $2 \mathrm{ml}$ of $50 \mathrm{mMTris}-\mathrm{HCl}$ buffer containing 20 $\mathrm{mM}$ EDTA, at $\mathrm{pH}$ 7.5. After adding $2 \mathrm{ml}$ ethanol (to precipitate the proteins), the homogenate was centrifuged at $3000 \mathrm{~g}$ for $40 \mathrm{~min}$ at $4^{\circ} \mathrm{C}$. The supernatant was used to determine the GSH level using 5, 5'-dithiobis (2-nitrobenzoic acid) (DTNB). The absorbance was measured at 412 $\mathrm{nm}$. Subsequently, the GSH level of the lung was expressed as nmol/g of tissue.

\section{Myeloperoxidase (MPO) activity}

The homogenized samples were frozen and thawed three times, and centrifuged at $1500 \mathrm{~g}$ for $10 \mathrm{~min}$ at $4^{\circ} \mathrm{C}$. Myeloperoxidase activity in the supernatant was determined by adding $100 \mathrm{~mL}$ of the supernatant to $1.9 \mathrm{~mL}$ of $10 \mathrm{mmol} / \mathrm{L}$ phosphate buffer $(\mathrm{pH} \mathrm{6.0)}$ and 1 $\mathrm{mL}$ of $1.5 \mathrm{mmol} / \mathrm{L}$ o-dianisidine hydrochloride containing $\quad 0.0005 \% \quad(w t / v o l)$ hydrogen peroxide. The changes in absorbance at 450 $\mathrm{nm}$ of each sample were recorded on a UV-vis spectrophotometer. Myeloperoxidase activity in tissues was expressed as micromoles per minute per milligram tissue ( $\mu \mathrm{mol} / \mathrm{min} / \mathrm{mg}$ tissue).

\section{Statistical analysis}

All statistical analyses were carried out using SPSS statistical software (SPSS for windows, version 20.0). All data were presented in mean ( \pm ) standard error (S.E.). Differences in measured parameters among four groups were analyzed with a nonparametric test (KruskalWallis). Dual comparisons between group sex habiting significant values were evaluated with a Mann-Whitney U-test $(p<0.05)$.

\section{Results}

\section{Histopathological examination}

Lung tissue samples of the rats in control group (Group 1) were microscobically normal (Figure 1) whereas there was a statistically significant difference between rats in diabetes group (Group 2) and those in diabetes + melatonin group (Group 3) $(p<0.05)$. Rats in diabetes group had more severe hyperplasia in bronchus associated lymphoid tissue (BALT) compared to those in diabetes + melatonin group (Figures 2 and 3). Histopathological findings of the lung tissue specimens were as follows:

Group 1 (Controls): Lung tissue samples were normal.

Group 2 (Diabetes): Thickened intralveolar septum, peribronchial cell infiltration and desquamation of bronchial epithelium, hyperemia in peribronchial vessels.

Group 3 (Diabetes + Melatonin): Mild thickening in the interalveolar septum and hyperemia in peribronchial vessels. There were statistically significant differences when compared to the findings in Group 2. Table 1 demonstrates histopathological findings.

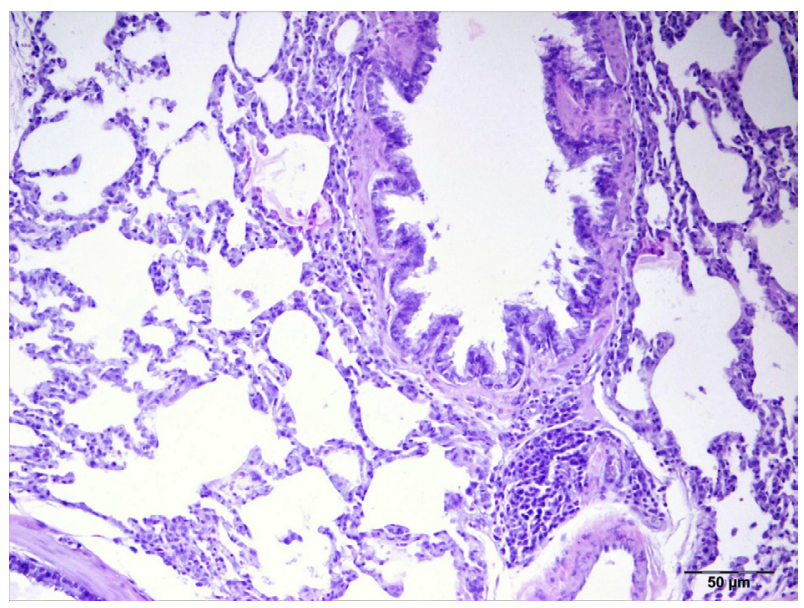

Figure 1 - Control group. In lung tissue samples normal histological view. 


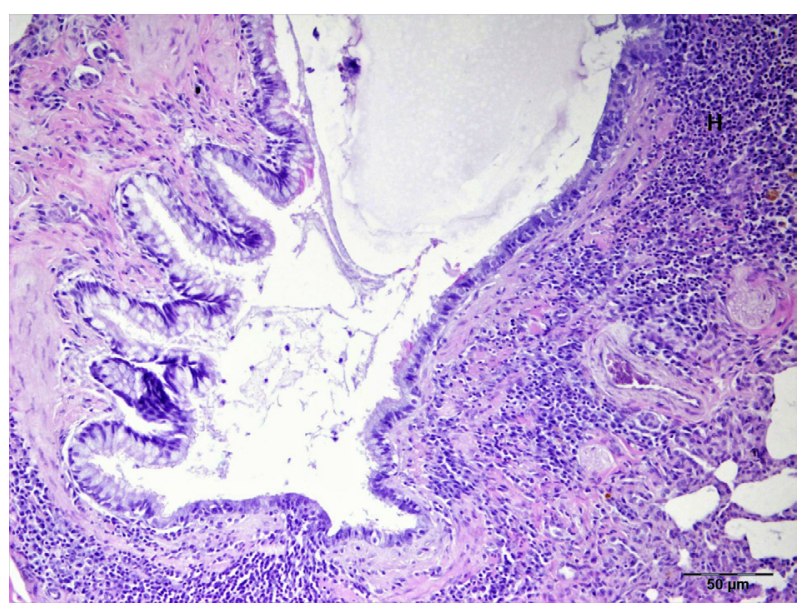

Figure 2 - Diabetes group. In lung tissue samples: thickened intralveolar septum, peribronchial cell infiltration, desquamation of bronchiol epithelium and hyperemia in peribronchial vessels.

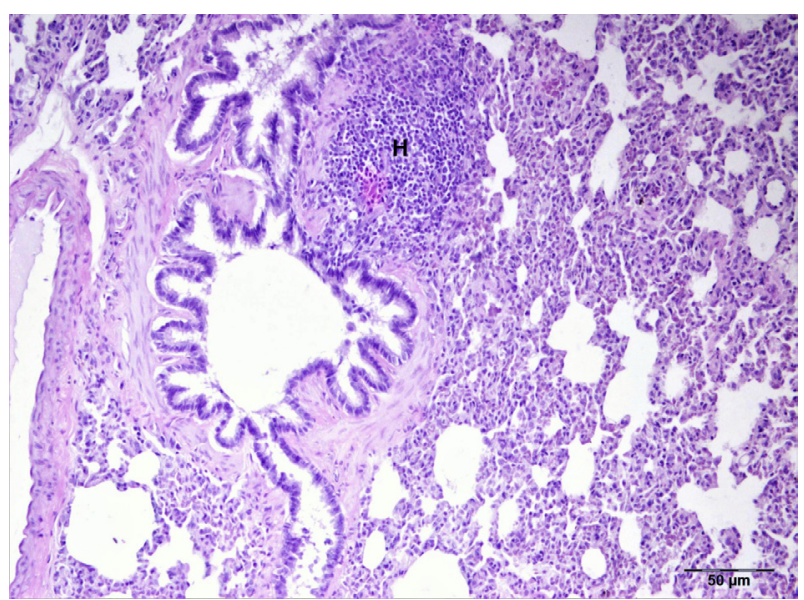

Figure 3 - Diabetes+melatonin group. In lung tissue samples: mild thickening in the interalveolar septum, hyperemia in peribronchial vessels.

Table 1 - Histopathological findings in lung tissue specimens.

\begin{tabular}{lccc} 
Microscopy & 1.Group(control) & 2.Group (diabetes) & 3.Group (diabetes+melatonin) \\
\hline $\begin{array}{l}\text { Thickened intraalveolar } \\
\text { septum }\end{array}$ & - & +++ & + \\
$\begin{array}{l}\text { Peribronchial cell } \\
\text { infiltration }\end{array}$ & - & +++ & + \\
$\begin{array}{l}\text { Hyperemia in peribronchial } \\
\text { vessels }\end{array}$ & - & +++ & ++ \\
\hline
\end{tabular}

\section{Immunohistochemical examination}

Cleaved-caspase 3 expression was quite low in lung tissue samples of the rats in control group (Figure 4). There was a statistically significant difference between the lung tissue samples of the rats in the diabetes group and the diabetes + melatonin group in regard to cleaved-caspase 3 levels $(p<0.05)$. Expression of cleaved-caspase 3 was severe in lung tissue samples of the rats in diabetes group whereas cleaved caspase 3 expression was seen to be at moderate level in diabetes + melatonin group (Figures 5 and 6).

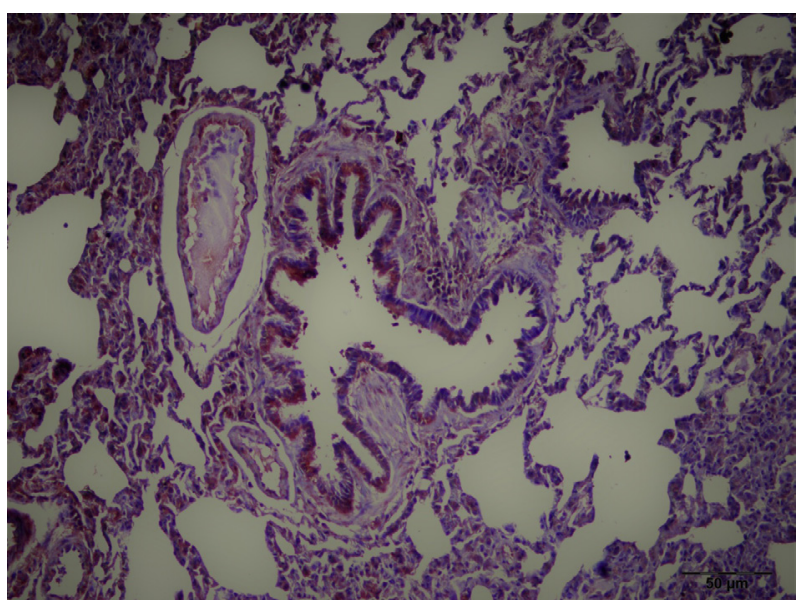

Figure 4 - Control group. Cleaved-caspase 3 low in lung tissue samples. 


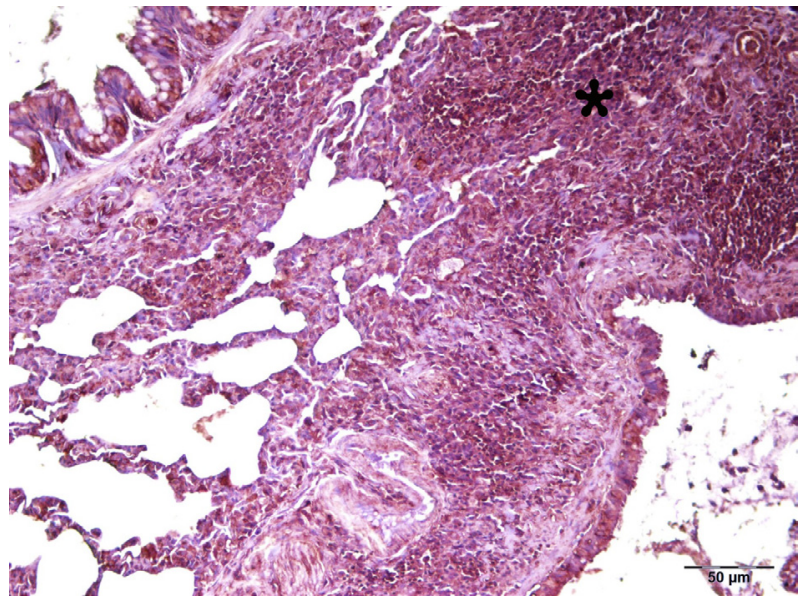

Figure 5 - Diabetes group. Severe expression of cleaved-caspase 3 in lung tissue.

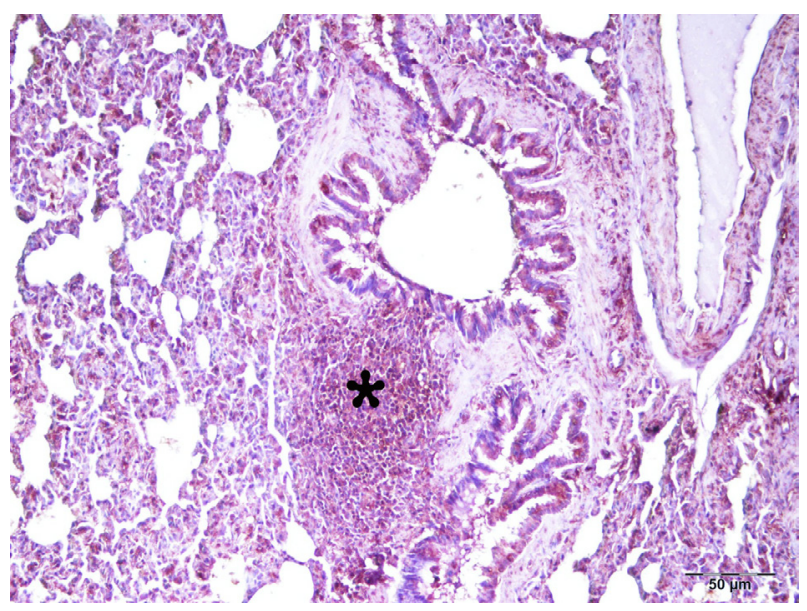

Figure 6 - Diabetes+melatonin group. Moderate expression of cleaved caspase 3 in lung tissue.

\section{Biochemical results}

Tissue MDA (LPO) levels of the lung tissue samples were found to be significantly higher in diabetes group compared to control group $(p<0.05)$. Administration of melatonin was found to significantly lower this increase in MDA levels $(p<0.05)$ (Figure 7$)$.

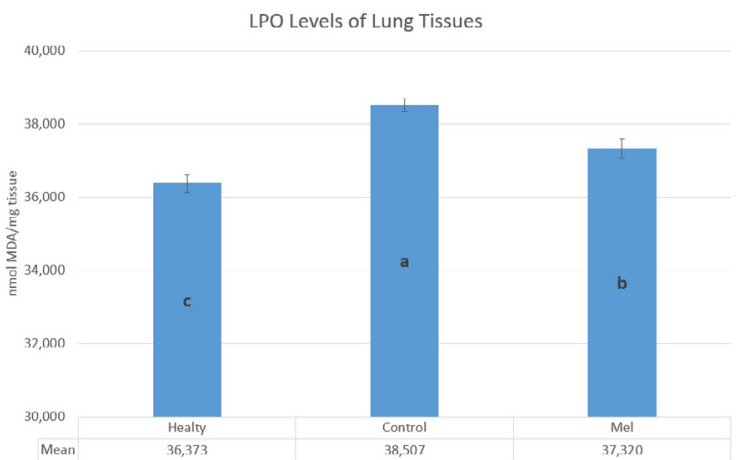

Figure 7 - LPO levels of lung tissues. Control, been made up of healthy rats; Diabetes, streptozotocin at a dose of $50 \mathrm{mg} / \mathrm{kg} /$ day for 5 days; Diabetes+Melatonin, streptozotocin at a dose of $50 \mathrm{mg} / \mathrm{kg} /$ day for 5 days and melatonin at a dose of $20 \mathrm{mg} / \mathrm{kg} /$ day between $28^{\text {th }}$ and $35^{\text {th }}$ days of the study; MDA, malondialdehyde. Same letters indicate similarity of groups $(p>0.05)$, different letters indicate differences of groups $(p<0.05)$. Note: All values measured were tested with one-way ANOVA and differences between the groups were determined by the Duncan Multiple Comparison Test.

SOD activity was found to be significantly lower in diabetes group compared to that in control group whereas SOD activity was significantly higher in diabetes + melatonin group than that in diabetes group $(p<0.05)$ (Figure 8).

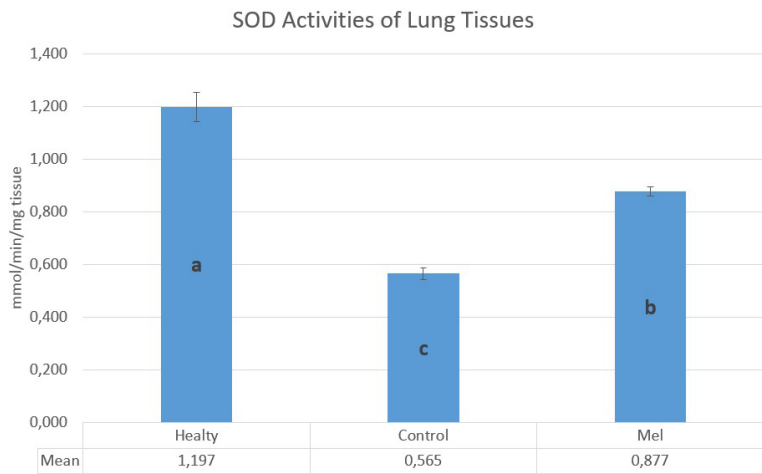

Figure 8 - SOD activities of lung tissues. Control, been made up of healthy rats; Diabetes, streptozotocin at a dose of $50 \mathrm{mg} / \mathrm{kg} /$ day for 5 days; Diabetes+Melatonin, streptozotocin at a dose of $50 \mathrm{mg} / \mathrm{kg} /$ day for 5 days and melatonin at a dose of $20 \mathrm{mg} / \mathrm{kg} /$ day between $28^{\text {th }}$ and $35^{\text {th }}$ days of the study; SOD, superoxide dismutase. Same letters indicate similarity of groups $(p>0.05)$, different letters indicate differences of groups $(p<0.05)$. Note: All values measured were tested with one-way ANOVA and differences between the groups were determined by the Duncan Multiple Comparison Test. 
GSH levels were significantly lower in diabetes group compared to control group whereas these levels were significantly higher in diabetes + melatonin group $(p<0.05)$ (Figure 9).

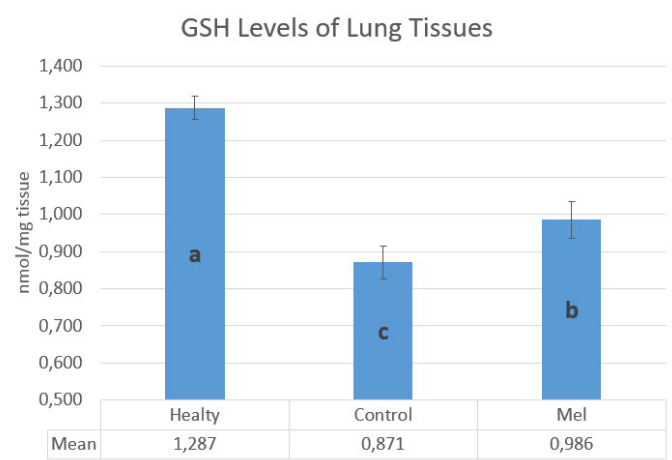

Figure 9 - GSH levels of lung tissues. Control, been made up of healthy rats; Diabetes, streptozotocin at a dose of $50 \mathrm{mg} / \mathrm{kg} /$ day for 5 days; Diabetes+Melatonin, streptozotocin at a dose of 50 $\mathrm{mg} / \mathrm{kg} /$ day for 5 days and melatonin at a dose of 20 $\mathrm{mg} / \mathrm{kg} /$ day between $28^{\text {th }}$ and $35^{\text {th }}$ days of the study; $\mathrm{GSH}$, glutathione. Same letters indicate similarity of groups $(p>0.05)$, different letters indicate differences of groups $(p<0.05)$. Note: All values measured were tested with one-way ANOVA and differences between the groups were determined by the Duncan Multiple Comparison Test.

CAT activity was not significantly different between control group and diabetes group whereas it was significantly higher in diabetes + melatonin group than that in diabetes group $(p<0.05)$ (Figure 10).

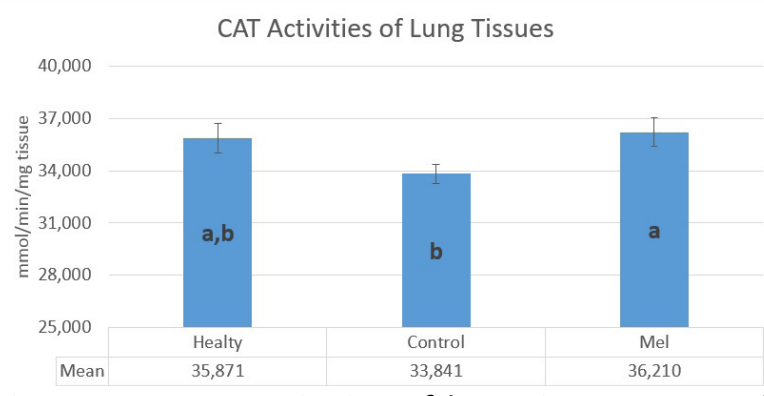

Figure 10 - CAT activities of lung tissues. Control, been made up of healthy rats; Diabetes, streptozotocin at a dose of $50 \mathrm{mg} / \mathrm{kg} /$ day for 5 days; Diabetes+Melatonin, streptozotocin at a dose of $50 \mathrm{mg} / \mathrm{kg} /$ day for 5 days and melatonin at a dose of $20 \mathrm{mg} / \mathrm{kg} /$ day between $28^{\text {th }}$ and $35^{\text {th }}$ days of the study; CAT, catalase. Same letters indicate similarity of groups ( $>0.05)$, different letters indicate differences of groups $(p<0.05)$. Note: All values measured were tested with one-way ANOVA and differences between the groups were determined by the Duncan Multiple Comparison Test.
MPO activity was significantly higher in diabetes group compared to control group $(p<0.05)$ whereas it was not significantly different between control group and diabetes + melatonin group ( $p>0.05)$, indicating that diabetes caused a significant increase in MPO activity however administration of melatonin lowered it to the levels seen in control group (Figure 11).

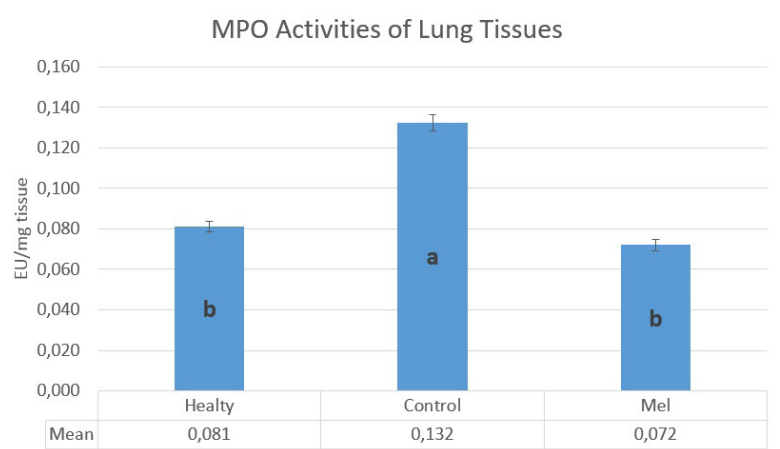

Figure 11 - MPO activities of lung tissues. Control, been made up of healthy rats; Diabetes, streptozotocin at a dose of $50 \mathrm{mg} / \mathrm{kg} /$ day for 5 days; Diabetes+Melatonin, streptozotocin at a dose of $50 \mathrm{mg} / \mathrm{kg} /$ day for 5 days and melatonin at a dose of $20 \mathrm{mg} / \mathrm{kg} /$ day between $28^{\text {th }}$ and $35^{\text {th }}$ days of the study; MPO, myeloperoxidase. Same letters indicate similarity of groups $(p>0.05)$, different letters indicate differences of groups $(p<0.05)$. Note: All values measured were tested with one-way ANOVA and differences between the groups were determined by the Duncan Multiple Comparison Test.

\section{Discussion}

Diabetes is the most common metabolic disease worldwide and it is the leading cause of death in develop countries ${ }^{19}$. There have been several studies focusing on the pathophysiologic alterations in lung tissue which developed secondary to poor diabetes control. These studies suggested that diabetes cause a decrease in microvascular reserve of the lungs, leading to development of hypoxia 
or it was also proposed that diabetes may worsen hypoxia in patients with chronic lung disease ${ }^{20}$.

This is the first study to show the positive effect of melatonin in treatment on diabetic lung tissue. We suggest that this effect may be produced by increased antioxidant capacity and reduced inflammation and apoptotic cel Ideath.

Several mechanisms were proposed to explain the tissue damage that is caused by hyperglycemia; increased influx of glucose through polyol pathway, an increase in advanced glycationend-products (AGEs) within the cytoplasm, an increase in the expression of AGEs receptors, protein kinase $\mathrm{C}$ isoform activation and hexosamine pathway activation. These mechanisms were thought to be activated by the increase in mitochondrial reactive oxygen species ${ }^{21}$.

Melatonin and its metabolites possess a high potential to bind free oxygen radicals. Therefore, they prevent inflammation and apoptosis ${ }^{8}$. Moreover, there have been studies demonstrating that melatonin decreases pulmonary damage. Torres et al. ${ }^{22}$ found that melatonin decreased the levels of pulmonary oxidative stress markers and increased both enzymatic and non-enzymatic antioxidant capacity. In line with these findings, we found a significant decrease in MDA levels of the lung tissue of diabetic rats receiving melatonin. Similar to the findings reported by Shin et $a l^{23}$, we found that melatonin administration caused inhibition of the inflammation in lung tissue and its administration caused tissue MPO levels to decrease down to the levels recorded in control group. It is well known that long-lasting inflammation and oxidative stress are two major causes of several chronic pulmonary diseases ${ }^{24}$. Melatonin is a highly effective antioxidant and it limits lung tissue damage by inhibition of oxidative through several pathways including removal of reactive free oxygen radicals, reduction of LPO (MDA) levels and also by activating $\mathrm{GSH}$ and $\mathrm{SOD}^{23,25}$. In our study; GSH, CAT and SOD activates were significantly increased in diabetic rats which we treated with melatonin.

In our previous rat study, we demonstrated the therapotic effect of melatonin on contrast-enhanced nephropathy in diabetic rats. We think that this effect of melatonin is produced by inhibition of IL-33 andoxidants ${ }^{26}$.

Oxidative stres resulting from hyperglycaemia induces apoptosis in endothelial cells. Apoptosis is regulated by caspases and caspase 3-related apoptotic pathway plays them ostcritical role in glucoseinduced apoptosis ${ }^{27}$. Puig et al. $^{28}$ reported that melatonin significantly reduced the expression of inflammation and apoptosis in a senescence-accelerated mice model. These findings are in line with those of ours. We found that hyperplasia in BALT worsened in diabetic rats whereas the hyperplasia in BALT was found to be significantly alleviated in diabetes + melatonin group. Moreover, expression of cleaved-caspase 3 was more severe in hyperplastic BALT of diabetic rats compared to controls, it was at moderate levels in diabetes + melatonin group, indicating a apoptosismodulating effect of melatonin, as reported in previous studies.

\section{Conclusion}

The administration of melatonin was associated with an increase in antioxidant capacity of the lung tissue of diabetic rats and it diminishes the expression of cleaved-caspase 3 , which is a reliable marker of inflammation and apoptotic cell death. 


\section{References}

1. Kinney GL, Black-Shinn JL, Wan ES, Make B, Regan E, Lutz S, Soler X, Silverman EK, Crapo J, Hokanson JE; COPD Gene Investigators. Pulmonary function reduction in diabetes with and without chronic obstructive pulmonary disease. Diabetes Care. 2014;37(2):389-95, doi: 10.2337/dc131435.

2. Klein OL, Krishnan JA, Glick S, Smith LJ. Systematic review of the association between lung function and Type 2 diabetes mellitus. Diabet Med. 2010 Sep;27(9):97787. doi: 10.1111/j.1464-5491.2010.03073.x.

3. Klein OL, Kalhan R, Williams MV, Peng J, Smith LJ. Lung spirometry parameters and diffusion capacity are decreased in patients with Type 2 diabetes. Diabet Med. 2012 Feb;29(2):212-9. doi: 10.1111/j.14645491.2011.03394.x.

4. Cavan DA, Parkes A, O'Donnell MJ, Freeman W, Cayton RM. Lung function and diabetes. Respir Med. 1991 May;85(3):257-8. PMID: 2132552.

5. Ofulue AF, Thurlbeck WM. Experimental diabetes and the lung. II. In vivo connective tissue metabolism. Am Rev Respir Dis. 1988 Aug;138(2):284-9. doI: 10.1164/ ajrccm/138.2.284.

6. Lazarus R, Sparrow D, Weiss ST. Handgrip strength and insulin levels: cross-sectional and prospective associations in the Normative Aging Study. Metabolism. 1997 Nov;46(11):1266-9. PMID: 9361683.

7. Pitocco D, Fuso L, Conte EG, Zaccardi F, Condoluci C, Scavone G, Incalzi RA, Ghirlanda G.The diabetic lung--a new target organ? Rev Diabet Stud. 2012 Spring;9(1):23-35. doi: 10.1900/RDS.2012.9.23.

8. Reiter RJ, Tan DX, Fuentes-Broto L. Melatonin: a multitasking molecule. Prog Brain Res. 2010;181:127-51. doi: 10.1016/ S0079-6123(08)81008-4.

9. Reiter RJ. The melatonin rhythm: both a clockand a calendar. Experientia. 1993 Aug 15;49(8):654-64. PMID: 8395408.

10.Di Bella G, Mascia F, Gualano L, Di Bella L. Melatonin anticancer effects: review. Int J Mol Sci. 2013 Jan 24;14(2):2410-30. doi: 10.3390/ijms14022410.
11.Nishida S, Segawa T, Murai I, Nakagawa S. Long-term melatonin administration reduces hyperinsulinemia and improves the altered fatty-acid compositions in type 2 diabetic rats via the restoration of Delta-5 desaturase activity. J Pineal Res. 2002;32(1):26-33. PMID: 11841597.

12.Peschke E, Frese T, Chankiewitz E, Peschke D, Preiss U, Schneyer U, Spessert R, Mühlbauer E. Diabetic Goto Kakizaki rats as well as type 2 diabetic patients show a decreased diurnal serum melatonin level and an increased pancreatic melatonin-receptor status. J Pineal Res. 2006;40(2):135-43. doI: 10.1111/j.1600-079X.2005.00287.x

13.Staiger $H$, Machicao F, Schäfer SA, Kirchhoff K, Kantartzis K, Guthoff $M$, Silbernagel $\mathrm{G}$, Stefan N, Häring $\mathrm{HU}$, Fritsche A. Polymorphisms within the novel type 2 diabetes risk locus MTNR1B determine $\beta$-cell function. PLoS One. 2008;3(12):e3962. doi: 10.1371/journal.pone.0003962.

14.Bouatia-Naji N, Bonnefond A, CavalcantiProença C, Spars $\varnothing$ T, Holmkvist J, Marchand M, Delplanque J, Lobbens S, Rocheleau G, Durand $E$, De Graeve $F$, Chèvre JC, BorchJohnsen K, Hartikainen AL, Ruokonen A, Tichet J, Marre M, Weill J, Heude B, Tauber $M$, Lemaire $K$, Schuit $F$, Elliott $P$, Jørgensen $T$, Charpentier G, Hadjadj S, Cauchi S, Vaxillaire $M$, Sladek R, Visvikis-Siest S, Balkau B, LévyMarchal C, Pattou F, Meyre D, Blakemore Al, Jarvelin MR, Walley AJ, Hansen T, Dina C, Pedersen O, Froguel P. A variant near MTNR1B is associated with increased fasting plasma glucose levels and type 2 diabetes risk. Nat Genet. 2008;41(1):89-94. doi: 10.1038/ng.277.

15.Lyssenko V, Nagorny CL, Erdos MR, Wierup $N$, Jonsson $A$, Spégel $P$, Bugliani $M$, Saxena $R$, Fex $\mathrm{M}$, Pulizzi N, Isomaa $\mathrm{B}$, Tuomi T, Nilsson P, Kuusisto J, Tuomilehto J, Boehnke M, Altshuler D, Sundler F, Eriksson JG, Jackson AU, Laakso M, Marchetti P, Watanabe RM, Mulder $\mathrm{H}$, Groop L. Common variant in MTNR1B associated with increased risk of type 2 diabetes and impaired early insulin secretion. Nat Genet. 2008;41(1):82-8. doi: 10.1038/ng.288.

16.Prokopenko I, Langenberg C, Florez JC, Saxena R, Soranzo N, Thorleifsson G, Loos 
RJ, Manning AK, Jackson AU, Aulchenko Y, Potter SC, Erdos MR, Sanna S, Hottenga JJ, Wheeler $E$, Kaakinen $M$, Lyssenko V, Chen WM, Ahmadi K, Beckmann JS, Bergman RN, Bochud $M$, Bonnycastle $L L$, Buchanan TA, Cao A, Cervino A, Coin L, Collins FS, Crisponi L, de Geus EJ, Dehghan A, Deloukas P, Doney AS, Elliott P, Freimer N, Gateva V, Herder C, Hofman A, Hughes TE, Hunt S, Illig $T$, Inouye $M$, Isomaa $B$, Johnson $T$, Kong $A$, Krestyaninova M, Kuusisto J, Laakso M, Lim $\mathrm{N}$, Lindblad $\mathrm{U}$, Lindgren $\mathrm{CM}, \mathrm{McCann} \mathrm{OT}$, Mohlke KL, Morris AD, Naitza $S$, Orrù $M$, Palmer CN, Pouta A, Randall J, Rathmann W, Saramies J, Scheet P, Scott LJ, Scuteri A, Sharp S, Sijbrands E, Smit JH, Song K, Steinthorsdottir V, Stringham HM, Tuomi T, Tuomilehto J, Uitterlinden AG, Voight BF, Waterworth $D$, Wichmann $H E$, Willemsen G, Witteman JC, Yuan X, Zhao JH, Zeggini $E$, Schlessinger D, Sandhu M, Boomsma DI, Uda M, Spector TD, Penninx BW, Altshuler $D$, Vollenweider $P$, Jarvelin MR, Lakatta $E$, Waeber G, Fox CS, Peltonen L, Groop LC, Mooser V, Cupples LA, Thorsteinsdottir U, Boehnke M, Barroso I, Van Duijn C, Dupuis J, Watanabe RM, Stefansson K, McCarthy MI, Wareham NJ, Meigs JB, Abecasis GR. Variants in MTNR1B influence fasting glucose levels. Nat Genet. 2009;41(1):77-81. doi: 10.1038/ ng.290.

17.Spars $\varnothing \mathrm{T}$, Bonnefond A, Andersson E, BouatiaNaji N, Holmkvist J, Wegner L, Grarup N, Gjesing AP, Banasik K, Cavalcanti-Proença $C$, Marchand $M$, Vaxillaire $M$, Charpentier G, Jarvelin MR, Tichet J, Balkau B, Marre M, Lévy-Marchal $C$, Faerch $K$, Borch-Johnsen K, Jørgensen T, Madsbad S, Poulsen P, Vaag A, Dina C, Hansen T, Pedersen O, Froguel P. G-allele of intronic rs10830963 in MTNR1B confers increased risk of Impaired fasting glycemia and type 2 diabetes through an Impaired glucose-stimulated insulin release studies Involving 19,605 europeans. Diabetes. 2009;58(6):1450-6. doi: 10.2337/ db08-1660.

18.Rönn T, Wen J, Yang Z, Lu B, Du Y, Groop $\mathrm{L}$, $\mathrm{Hu} \mathrm{R}$, Ling $\mathrm{C}$. A common variant in MTNR1B, encoding melatonin receptor $1 \mathrm{~B}$, is associated with type 2 diabetes and fasting plasma glucose in Han Chinese individuals. Diabetologia. 2009;52(5):830-3. doi: 10.1007/s00125-009-1297-8.

19.King $H$, Aubert RE, Herman WH. Global burden of diabetes, 1995-2025: prevalence, numerical estimates, and projections. Diabetes Care. 1998 Sep;21(9):1414-31. PMID: 9727886.

20. Hsia CC, Raskin P. Lung function changes related to diabetes mellitus. Diabetes Technol Ther. 2007 Jun;9 Suppl 1:S73-82. dol: 10.1089/dia.2007.0227.

21.Brownlee M. The pathobiology of diabetic complications: a unifying mechanism. Diabetes. 2005 Jun;54(6):1615-25. PMID: 15919781.

22.Torres F, González-Candia A, Montt C, Ebensperger G, Chubretovic $M$, SerónFerré $M$, Reyes RV, Llanos AJ, Herrera EA. Melatonin reduces oxidative stress and improves vascular function in pulmonary hypertensive newborn sheep. J Pineal Res. 2015 Apr;58(3):362-73. doi: 10.1111/ jpi.12222.

23.Shin IS, Shin NR, Park JW, Jeon CM, Hong JM, Kwon OK, Kim JS, Lee IC, Kim JC, Oh SR, Ahn KS. Melatonin attenuates neutrophil inflammation and mucus secretion in cigarette smoke-induced chronic obstructive pulmonary diseases via the suppression of Erk-Sp1 signaling. J Pineal Res. 2015 Jan;58(1):50-60. doi: 10.1111/ jpi.12192.

24.Angelis N, Porpodis $\mathrm{K}$, Zarogoulidis $\mathrm{P}$, Spyratos D, Kioumis I, Papaiwannou A, Pitsiou G, Tsakiridis K, Mpakas A, Arikas S, Tsiouda T, Katsikogiannis N, Kougioumtzi I, Machairiotis N, Argyriou M, Kessisis G, Zarogoulidis K. Airway inflammation in chronic obstructive pulmonary disease. J Thorac Dis. 2014 Mar;6 Suppl 1:S167-72. doi: 10.3978/j.issn.2072-1439.2014.03.07.

25.El-Sokkary GH, Cuzzocrea S, Reiter RJ. Effect of chronic nicotine administration on therat lung and liver: beneficial role of melatonin. Toxicology. 2007 Sep 24;239(1-2):60-7. doI: 10.1016/j.tox.2007.06.092.

26.Onk D, Onk OA, Turkmen K, Erol HS, Ayazoglu TA, Keles ON, Halici M, Topal E. Melatonin attenuates contrast-ınduced nephropathy in diabetic rats: the role of Interleukin-33 and oxidative stress. 
Mediators Inflamm. 2016;2016:9050828. doi: $10.1155 / 2016 / 9050828$.

27. Ho FM, Liu SH, Liau CS, Huang PJ, Lin-Shiau SY. High glucose-induced apoptosis in human endothelial cells is mediated by sequential activations of c-Jun $\mathrm{NH}(2)$-terminal kinase and caspase-3.Circulation. 2000 Jun 6;101(22):2618-24. PMID: 10840014.
28.Puig Á, Rancan L, Paredes SD, Carrasco A, Escames G, Vara E, Tresguerres JA. Melatonin decreases the expression of inflammation and apoptosis markers in the lung of a senescence-accelerated mice model. Exp Gerontol. 2016 Mar;75:1-7. doi: 10.1016/j. exger.2015.11.021.

\section{Correspondence:}

Didem Onk

Anesthesiology Department, Erzincan

University

24030, Erzincan Turkey

Phone: +90 5053856322

d.hesapdar@gmail.com

Received: Dec 15, 2017

Review: Feb 12, 2018

Accepted: Mar 13, 2018
Conflict of interest: none

Financial source: Erzincan University
${ }^{1}$ Research performed at Atatürk University Animal Laboratories, Erzurum, Turkey. 